\title{
KLASIFIKASI LEKSIKON DAN FUNGSI NILAI SOSIAL ORNAMEN TRADISIONAL RUMAH BANJAR
}

\section{CLASSIFICATION OF LEXICON AND SOCIAL VALUE FUNCTION OF BANJAR HOUSE TRADITIONAL ORNAMENTS}

\author{
Hestiyana \\ Balai Bahasa Kalimantan Selatan \\ Ponsel: 082156614445; Pos-el: hestiyana21@gmail.com
}

Naskah Diterima Tanggal: 4 Januari 2020; Direvisi Akhir Tanggal: 23 Juni 2020; Disetujui Tanggal: 24 Juni 2020 DOI: https://doi.org/10.26499/mab.v14i1.314

\begin{abstract}
Abstrak
Penelitian ini menganalisis klasifikasi leksikon dan fungsi nilai sosial ornamen tradisional rumah Banjar. Penelitian ini bertujuan mendeskripsikan klasifikasi leksikon dan fungsi nilai sosial ornamen tradisional rumah Banjar. Penelitian ini menggunakan metode deskriptif dengan pendekatan semantik budaya. Sumber data yang digunakan berupa data lisan dan data tertulis mengenai leksikon ornamen tradisional rumah Banjar dan fungsi nilai sosialnya. Pengambilan data dilakukan di Kabupaten Banjar dan Kota Banjarmasin. Hal ini dilakukan berdasarkan nilai sejarah kedua daerah tersebut yang pernah menjadi pusat Kerajaan Banjar. Dalam pengumpulan data digunakan teknik observasi, wawancara, dan dokumentasi. Hasil analisis data disajikan dengan metode penyajian informal, yakni dipaparkan dengan kata-kata serta uraian kalimat. Penelitian ini dapat mengungkap klasifikasi leksikon dan fungsi nilai sosial ornamen tradisional rumah Banjar. Dari hasil penelitian ditemukan bahwa leksikon ornamen tradisional rumah Banjar dapat diklasifikasikan berdasarkan sarana bangunan yang diberikan ukiran atau motif, yaitu (1) pucuk bubungan, (2) pilis atau papilis, (3) tangga, (4) palatar, (5) lawang, (6) lalungkang, (7) watun, (8) tataban, (9) tawing halat, dan (10) sampukan balok. Adapun fungsi nilai sosial ornamen tradisional rumah Banjar, yaitu (1) nilai silaturahmi, (2) nilai gotong royong, (3) nilai tolong-menolong, dan (4) nilai musyawarah.
\end{abstract}

Kata-kata kunci: fungsi sosial; leksikon; ornamen tradisional; rumah Banjar

\begin{abstract}
This study analyzes the lexicon classification and the social value function of traditional Banjar house ornaments. The study aims at describing the classification of the lexicon and the social value function of the traditional ornaments of the Banjar house. The study uses a descriptive method with a cultural semantic approach. The data sources used is in the form of oral data and written data about the traditional ornament lexicon of Banjar house and its social value function data are collected in Banjar District and Banjarmasin City. This was done based on the historical value of the two regions that were once the center of Banjar Kingdom. Techniques of data collection apply
\end{abstract}

(C)2020, Mabasan 14 (1), 45-56 
observation, interviews, and documentation. The results of data analysis are presented with an informal presentation method, which is presented with words and sentence descriptions. The study can reveal the classification of the lexicon and the social value function of the traditional ornaments of Banjar house. The results of the study shows that the traditional ornament lexicon of Banjar house can be classified based on its carved buildings or motifs, namely are: (1) pucuk bubungan, (2) pilis or papilis, (3) stairs, (4) terrace, (5) door, (6) window, (7) watun, (8) tataban, (9) tawing halat, and (10) sampukan balok. Meanwhile, the social value function of the traditional ornament of the Banjar house, namely are: (1) the value of hospitality, (2) the value of mutual cooperation, (3) the value of helping and helping, and (4) the value of deliberation.

Keywords: lexicon; social function; traditional ornaments; Banjar house

\section{Pendahuluan}

Sejak dahulu masyarakat Banjar tidak bisa dipisahkan dengan sungai yang merupakan sistem transportasi utama sehingga kebudayaan yang berkembang pun tidak jauh dari kehidupan perairan. Nuralang (2006:49) menyatakan, secara geografis Banjarmasin berada di wilayah laut Jawa. Posisi Banjarmasin terletak pada suatu delta yang dikelilingi oleh Sungai Martapura dan Barito. Demikian juga dengan tradisi dan budaya dalam membangun sebuah rumah. Kehidupan masyarakat Banjar yang dipengaruhi kondisi alam dan sebagian besar tanah rawa menjadikan desain rumah tradisional pun banyak menggunakan konstruksi rumah panggung.

Rumah tradisional Banjar merupakan salah satu kekayaan budaya dan warisan nenek moyang yang tidak ternilai. Selain memiliki fungsi tempat istirahat, rumah tradisional Banjar juga sarat akan nilai-nilai sosial, religiusitas, dan simbolisasi kehidupan masyarakat Banjar. Hal ini seperti yang dikemukakan Setiadi dkk (2017) bahwa bidang spiritual dan material menjadi kebutuhan manusia. Hal ini menunjukkan bahwa kebudayaan menjadi sumber kebutuhan manusia.

$$
\text { Rumah tradisional Banjar }
$$
merupakan salah satu wujud kebudayaan fisik karena salah satu hasil karya manusia yang bersifat konkret dan berwujud benda yang dapat diraba serta dilihat. Rumah tradisional mampu beradaptasi dengan lingkungan alam sehingga hadirnya di tengah-tengah pembangunan rumah modern sebagai bukti eksistensi rumah tradisional Banjar. Hal ini juga menunjukkan kekayaan budaya masyarakat Banjar yang menjadi bukti kebinekaan Indonesia. 
Arsitektur rumah tradisional dalam kehidupan masyarakat tanpa budaya tulis dapat mencerminkan tatanan, relasi sosial, gender, serta ritual dalam masyarakat (Rapoport dalam Nurhafni, 2017:577).

Rumah tradisional Banjar mempunyai keunikan yang merefleksikan kebudayaan masyarakat pendukungnya. Pembangunan rumah tradisional juga sarat dengan nilai dan norma yang menjadi tatanan kehidupan masyarakat. Adanya masyarakat yang masih mempertahankan keberadaan rumah tradisional merupakan salah satu bentuk tanggung jawab dalam menjaga dan melestarikan warisan kebudayaan daerah. Selain mempunyai peran sebagai tempat tinggal, rumah tradisional Banjar juga menggambarkan nilai filosofis dan religiusitas pada ornamen-ornamennya. Hal inilah yang melatarbelakangi penelitian ini dilakukan.

Di samping itu, adanya kekhawatiran akan tergerusnya keberadaan rumah tradisional Banjar dengan model arsitektur modern melandasi dilakukannya penelitian ini. Tentunya menarik untuk diteliti dan dianalisis lebih mendalam lagi mengenai rumah tradisional Banjar dari aspek leksikon dan fungsi nilai sosial yang menjadi cerminan kebudayaan Banjar.

Penelitian yang relevan dengan penelitian ini yakni "Bentuk dan Makna Leksikon Pembentuk Rumah Adat Kudus” yang dilakukan Priambada (2011). Hasil penelitiannya menunjukkan bahwa bentuk satuan lingual leksikon, antara lain (1) bentuk kata, berupa kata dasar, jadian, ulang, serta majemuk dan (2) bentuk frasa endosentrik atributif. Kemudian, makna leksikonnya, yakni makna leksikal, gramatikal, konotatif, simbolik, dan filosofis.

Penelitian lain yang terkait dengan rumah tradisional Banjar adalah penelitian Dahliani (2014) yang berjudul "Eksistensi Rumah Tradisional Banjar sebagai Identitas Kawasan Bersejarah di Kelurahan Kuin Utara, Banjarmasin". Dari penelitian tersebut, diketahui bahwa di Kelurahan Kuin Utara hanya terdapat 14 rumah tradisional. Salah satu cara melestarikannya yakni dengan melakukan rehabilitasi rumah yang terdapat kerusakan dan yang sebagian telah dimodifikasi. Selanjutnya, dilakukan rekonstruksi rumah yang tidak memiliki ciri tradisional. 
Dari hasil penelitian sebelumnya, belum ada yang mengkaji klasifikasi leksikon dan fungsi nilai sosial ornamen tradisional rumah Banjar. Dengan demikian, kajian ini mengungkap klasifikasi leksikon dan fungsi nilai sosial ornamen tradisional rumah Banjar. Fokus masalah dalam penelitian ini berkaitan dengan (1) klasifikasi leksikon ornamen tradisional rumah Banjar dan (2) fungsi nilai sosial ornamen tradisional rumah Banjar.

Tujuan penelitian ini adalah (1) mendeskripsikan klasifikasi leksikon ornamen tradisional rumah Banjar dan (2) mendeskripsikan fungsi nilai sosial ornamen tradisional rumah Banjar. Dari tujuan tersebut diharapkan penelitian dapat memberikan manfaat untuk menambah pengetahuan tentang rumah tradisional Banjar sekaligus menambah wawasan apresiasi kebudayaan daerah, terutama kebudayaan Banjar.

\section{Landasan Teori}

Semantik adalah cabang ilmu linguistik. Hal ini seperti yang dikemukakan Verhaar (2006:13) bahwa semantik membahas tentang arti dan makna. Leksikografi menjadi contoh deskripsi dari semantik dan setiap leksem diberikan perian dan maknanya.
Chaer (2007:5) menjelaskan asal kata leksikon, yakni lexicon berasal dari Yunani Kuno kata, ucapan, atau acara berbicara. Leksikon sekerabat dengan leksem, leksikografi, leksikograf, dan leksikal. Kemudian, kosakata menjadi istilah yang muncul ketika mencari kata dan istilah yang tidak berbau Barat. Leksem bagian satuan leksikon yang mempunyai makna. Leksikon dapat disebut sebagai kosakata atau perbendaharaan kata, sedangkan leksem disebut juga dengan kata.

Leksikon didefinisikan sebagai susunan daftar istilah atau kata, glosari, kosakata, ataupun perbendaharaan kata serta kamus (Tim Redaksi, 2009:343). Pendapat yang sama dijelaskan Kridalaksana (2011:142) bahwa leksikon, antara lain (1) komponen bahasa yang mencakup keseluruhan informasi makna dan penggunaan kata; (2) perbendaharaan kata atau kosakata yang dimiliki seseorang; dan (3) susunan kata seperti kamus yang pendefinisiannya disingkat.

Allport (dalam Abdulsyani, 2002:49) mengemukakan bahwa nilai adalah suatu ukuran mengenai sikap atau perasaan baik dan buruk ataupun benar dan salah terhadap objek material ataupun nonmaterial. Hal yang sama 
dikemukakan Fraenkel (dalam Sumantri \& Sauri, 2006:5) yang menyatakan bahwa nilai ialah ketika seseorang memikirkan tentang konsep yang dianggapnya mempunyai arti. Spranger (dalam Mulyana, 2004:32) menjelaskan orientasi nilai yang dijadikan pedoman, yaitu nilai teoritik, ekonomis, estetik, sosial, politik, dan agama.

Penelitian ini lebih menitikberatkan pada nilai sosial. Dalam kehidupan masyarakat Banjar, nilai sosial berhubungan dengan nilainilai luhur kehidupan bermasyarakat, yakni lebih mengutamakan kepentingan masyarakat daripada kepentingan individual. Dengan demikian, penelitian ini menggunakan pemahaman tentang teori leksikon yang dikemukakan Chaer (2007) dan orientasi nilai yang dilihat dari fungsi nilai sosial sebagaimana dikemukakan Spranger (dalam Mulyana, 2004).

\section{Metode Penelitian}

Metode yang digunakan dalam penelitian ini adalah deskriptif kualitatif dengan pendekatan semantik budaya. Metode deskriptif merupakan metode yang memaparkan data secara apa adanya dan bersifat objektif (Ibnu dkk, 2003:8). Dengan metode deskriptif ini, dapat diuraikan mengenai keadaan bahasa, gejala, atau pun kelompok tertentu.

Deskriptif kualitatif adalah penelitian yang mempunyai tujuan mendeskripsikan suatu fenomena sosial, sikap dan kepercayaan, baik individu ataupun kelompok (Saodih, 2010:60). Kemudian, Moleong (2015:6) mengemukakan bahwa penelitian kualitatif menghasilkan suatu prosedur analisis yang tidak menggunakan analisis statistik.

Santosa (2014:27) menyatakan bahwa tujuan penelitian kualitatif adalah memaparkan fenomena budaya yang bersifat tersembunyi. Hal ini senada dengan pendapat Mahsun (2017:397) yang menyatakan bahwa tujuan analisis kualitatif lebih menekankan pada penjelasan kebermaknaan fenomena yang menjadi objek penelitian.

Sumber data dalam penelitian ini berupa data lisan dan data tertulis mengenai leksikon ornamen tradisional rumah Banjar dan fungsi nilai sosialnya. Pengambilan data dilakukan di Kabupaten Banjar dan Kota Banjarmasin. Pengambilan data di Kabupaten Banjar meliputi Kecamatan Martapura dan Kecamatan Karang 
Intan. Kemudian, Kota Banjarmasin meliputi Kecamatan Banjarmasin Utara.

Hal ini dilakukan berdasarkan nilai sejarah kedua daerah tersebut yang pernah menjadi pusat Kerajaan Banjar. Selain itu, di daerah itu masih ditemukan beberapa bangunan rumah tradisional Banjar. Adapun pengumpulan data dilakukan melalui teknik observasi (pengamatan), wawancara, serta dokumentasi.

Moleong (2015:157) mengemukakan bahwa observasi (pengamatan) akan mengasah kemampuan perilaku, kepercayaan, dan kebiasaan seorang peneliti. Pendapat yang sama dikemukakan Sudikan (2017:96) yang menyatakan bahwa dalam teknik observasi (pengamatan) diperlukan alat bantu untuk menunjang pengamatan peneliti yang terbatas.

Kemudian, Moleong (2015:186) menjelaskan bahwa teknik wawancara dilakukan dengan tujuan tertentu. Wawancara tersebut dilakukan oleh pewawancara yang mengajukan pertanyaan dan terwawancara yang menjawab atas pertanyaan tersebut. Selanjutnya, Sudikan (2017:101) mengatakan bahwa peneliti terlebih dahulu membuat daftar pertanyaan yang menjadi pedoman wawancara sebelum melakukan wawancara dengan informan. Perlu diingat bahwa pedoman wawancara tersebut bersifat fleksibel karena bergantung situasi dan kondisi di lapangan.

Wawancara dilakukan dengan beberapa narasumber. Prosedur pemilihan narasumber dilakukan dengan teknik snowball sampling, yakni secara bertahap. Tahap pertama dilakukan identifikasi terhadap seseorang yang dianggap mampu memberikan infomasi untuk diwawancarai. Lalu, orang tersebut menjadi informan untuk mengidentifikasi informan lainnya yang dijadikan sampel dan dapat memberikan informasi yang diperlukan. Proses ini berlangsung sampai terpenuhi jumlah sampel yang diperlukan (Silalahi, 2012:273).

Selanjutnya, Moleong (2015:217) mengemukakan bahwa dokumen merupakan sumber data yang sudah lama digunakan untuk menguji ataupun menafsirkan serta meramalkan.

Analisis data yang digunakan dalam penelitian ini adalah (1) data hasil wawancara ditranskrip dalam bentuk tulis; (2) data diidentifikasi sesuai dengan klasifikasi leksikon dan fungsi nilai sosial ornamen; (3) data yang ditemukan akan dideskripsikan ke 
dalam klasifikasi leksikon; (4) data yang ditemukan akan dideskripsikan fungsi nilai sosial ornamennya; dan (5) masing-masing data akan disinkronkan sehingga diperoleh keakuratan dan kesesuaian data.

Tahapan terakhir adalah penyajian analisis data, yakni dengan dengan pemaparan kalimat-kalimat yang menggambarkan keseluruhan hasil temuan. Sehubungan dengan tahap analisis data, Sudaryanto (2015:241) menjelaskan hasil analisis data dapat disajikan dengan metode informal dan formal. Hasil analisis data dalam penelitian ini akan dideskripsikan melalui hasil kajian dengan metode informal.

\section{Pembahasan}

Masyarakat Banjar memiliki rumah tradisional Banjar, antara lain: (1) bubungan tinggi, (2) gajah baliku, (3) gajah manyusu, (4) balai laki, (5) balai bini, (6) palimasan, (7) palimbangan, (8) cacak burung atau anjung surung, (9) tadah alas, (10) joglo, (11) lanting. Hasil wawancara dengan bapak Suriansyah dan bapak Ruslan dijelaskan bahwa dari tipe rumah tradisional tersebut terdapat ornamen sebagai ragam hias rumah tradisional
Banjar, terutama rumah tradisional Banjar tipe bubungan tinggi, tipe gajah baliku, dan tipe palimbangan.

Ornamen arsitektur rumah tradisional Banjar disebut dengan istilah tatah, yakni bentuk ukiran relief (tatah surut), bentuk ukiran tiga dimensi (tatah babuku), serta bentuk ukiran bakurawang (tatah baluang). Berikut akan dipaparkan leksikon ornamen tradisional rumah Banjar.

\subsection{Klasifikasi Leksikon Ornamen Tradisional Rumah Banjar \\ Berdasarkan hasil wawancara} dengan ibu Ramlah dan ibu Nooraini, dijelaskan bahwa ornamen tradisional rumah Banjar biasanya disesuaikan dengan ukiran dan motif.

Jadi, leksikon yang terdapat pada ornamen tradisional rumah Banjar dapat diklasifikasikan berdasarkan sarana bangunan yang diberi ukiran atau motif. Berikut hasil kajiannya.

\section{1). Pucuk Bubungan}

Dalam rumah tradisional Banjar dengan tipe bubungan tinggi, ditemukan pucuk yang lancip atau sering disebut layang-layang. Pucuk pada rumah tradisional tersebut terdapat ukiran dengan motif (1) tumbuhan paku alai, (2) bogam, dan (3) tombak (keris). Kemudian, pada tipe palimasan terdapat ornamen 
dengan bentuk sungkul yang memiliki motif (1) anak catur, (2) piramida, dan (3) bulan bintang. Selanjutnya, rumah tradisional dengan tipe palimbangan, balai laki, balai bini, serta cacak burung terdapat ornamen dengan ukiran jamang dengan motif (1) anak catur yang kiri kanannya terdapat tumbuhan paku alai dan (2) halilipan (babalungan ayam).

2). Pilis (Papilis)

Pada pilis (papilis) ini, ditemukan ornamen tumbuhan kasau dan penutup ujung kasau bubungan, banturan, dan batis tawing (kaki dinding) di bagian luar. Leksikon yang digunakan pada pilis atau papilis yakni (1) rincung gagatas, (2) pucuk rabung, (3) tali bapintal, (4) dedaunan, (5) kumbang bagantung, (6) paku alai, (7) kulat karikit, (8) gagalangan, (9) iitikan, (10) sarangwanyi, (11) kambang cangkih, (12) teratai, dan (13) gigi haruan.

3) Tangga

Pada rumah tradisional Banjar, tangga merupakan bagian bangunan rumah yang sangat vital karena sebagai sarana pertama ketika akan memasuki rumah. Tangga ini dapat dibagi menjadi beberapa bagian, yakni puncak pohon tangga, panapih tangga, pagar tangga, dan kisi-kisi pagar tangga.

Leksikon ornamen yang terdapat pada pucuk tangga, yaitu (1) kanas atau nenas, (2) kembang melati yang kuncup, (3) tongkol daun pakis, (4) belimbing, (5) payung, dan (6) bulan sabit. Kemudian, leksikon ornamen yang terdapat pada panapih tangga, antara lain (1) tali bapintal, (2) dedaunan, (3) buah mengkudu, dan (4) sulur-suluran. Lalu, leksikon ornamen yang terdapat pada pagar tangga, yakni tali bapintal. Selanjutnya, leksikon ornamen yang ditemukan pada kisi-kisi pagar tanda meliputi (1) bogam melati, (2) galang bakait, (3) anak catur, (4) motif huruf S, dan (5) geometris.

4). Palatar

Palatar atau teras merupakan bagian depan rumah yang sering diberi hiasan ornamen, seperti jurai samping kiri dan kanan atas, batis tawing (kaki dinding), serta kandang rasi. Leksikon ornamen yang ditemukan pada jurai, yakni (1) hiris gagatas, (2) pucuk rabung, (3) daun paku, dan (4) sarang wanyi. Pada batis tawing terdapat leksikon ornamen, yaitu (1) dedaunan, (2) 
sulur-suluran, dan (3) buah mengkudu. Kemudian, leksikon ornamen yang terdapat pada kandang wasi, antara lain (1) sulur-suluran, (2) anak catur, (3) geometris, (4) bogam melati, dan (5) gagalangan.

5) Lawang

Bagian-bagian lawang atau pintu yang mendapat ornamen, yakni dahi lawang, jurai lawang, dan daun lawang. Leksikon ornamen yang terdapat pada dahi lawang, yaitu (1) tali bapintal, (2) sulur-suluran, (3) bunga-bunga dengan tambahan kaligrafi Arab. Kemudian, leksikon ornamen yang ditemukan pada jurai lawang yang terdapat pula pada dahi lawang, yaitu (1) tali bapintal, (2) sulur-suluran, dan (3) bunga-bunga yang ditambahkan kaligrafi Arab. Selanjutnya, leksikon ornamen yang terdapat pada daun lawang, yakni (1) tali bapintal, (2) hiris gagatas, (3) pancar matahari.

6) Lalungkang

Leksikon ornamen tradisional rumah Banjar yang terdapat pada lalungkang atau jendela, yakni tatah bakurawang dengan motif meliputi (1) bulan penuh, (2) bulan sahiris, (3) bulan bintang, (4) bintang sudut lima, (5) daun jalukap, dan (6) daun jaruju.
7) Watun

Watun merupakan bagian rumah yang memiliki lantai terbuka. Bagian watun ini diberikan ornamen pada panapihnya atau dinding watun. Leksikon ornamennya, yaitu (1) tali bapintal, (2) sulur-suluran, dedaunan, (4) kambang taratai, (5) kaca piring, (7) kananga, (8) kambang matahari, dan (9) buahbuahan.

8) Tataban

Letak tataban ada pada sepanjang kaki dinding bagian dalam di ruang panampik basar. Leksikon ornamen yang diberikan di sepanjang tataban, antara lain (1) tali bapintal, (2) dedaunan, dan (3) sulursuluran.

9) Tawing Halat

Tawing halat adalah dinding pembatas utama dalam sebuah rumah. Leksikon ornamen yang terdapat pada tawing halat meliputi (1) tali bapintal, (2) buah, dan (3) daun-daunan dengan kombinasi kaligrafi Arab.

10) Sampukan balok

Sampukan balok merupakan pertemuan dua atau tiga ujung balok. Leksikon ornamen yang terdapat pada sampukan balok 
tersebut, yaitu (1) dedaunan dan (2) garis-garis geometris.

\subsection{Fungsi Nilai Sosial Ornamen Tradisional Rumah Banjar}

Dari keseluruhan ornamen tradisional yang terdapat pada rumah Banjar, ditemukan nilai-nilai yang mencerminkan kehidupan masyarakat Banjar. Hasil wawancara dengan kelima informan diketahui bahwa ornamenornamen tersebut mempunyai fungsi persaudaraan, semangat persatuan, lingkungan alam yang subur, serta kaligrafi Arab yang bersumber dari ajaran agama Islam, yakni dua kalimat syahadat, shalawat, ataupun nama-nama khalifah. Ornamen dengan motif tumbuh-tumbuhan yang subur merupakan perwujudan kehidupan masyarakat Banjar yang dikelilingi pepohonan dan hutan yang subur.

Masyarakat Banjar juga senantiasa menjaga tali silaturahmi dan menjaga persatuan dan kesatuan. Hal ini dilambangkan dengan banyaknya ornamen ukiran dengan motif berbeda yang digunakan dalam rumah Banjar. Kemudian, nilai sosial gotong royong terlihat ketika salah satu anggota masyarakat Banjar membangun sebuah rumah. Nilai tolong-menolong juga tampak dalam pembangunan rumah ketika diadakan upacara selamatan.
Masyarakat Banjar bersama-sama membantu menyiapkan segala keperluan. Hasil wawancara dengan bapak Arbani dijelaskan bahwa dalam menentukan ornamen yang sesuai dengan rumah, masyarakat Banjar memberikan pendapat dan saran. Hal ini mencerminkan fungsi nilai musyawarah yang menyatu dalam kehidupan seharihari masyarakat Banjar.

\section{Penutup}

Dari hasil analisis data ditemukan bahwa leksikon ornamen tradisional rumah Banjar dapat diklasifikasikan berdasarkan sarana bangunan yang diberi ukiran atau motif, yakni (1) pucuk bubungan, (2) pilis atau papilis, (3) tangga, (4) palatar, (5) lawang, (6) lalungkang, (7) watun, (8) tataban, (9) tawing halat, dan (10) sampukan balok. Adapun, fungsi nilai sosial ornamen tradisional rumah Banjar, antara lain (1) nilai silaturahmi, (2) nilai gotong royong, (3) nilai tolong-menolong, dan (4) nilai musyawarah.

Ornamen tradisional rumah Banjar yang masih dilestarikan masyarakat Banjar tentunya sarat akan simbolsimbol kebudayaan Banjar serta menjadi identitas yang mencerminkan karakteristik masyarakatnya serta 
menumbuhkan rasa sayang dan cinta terhadap budaya daerah. Selain itu, ornamen tradisional itu juga mampu menumbuhkan rasa kebanggaan akan keanekaragaman kebudayaan dan kebinekaan di Indonesia.

\section{Daftar Pustaka}

Abdulsyani. (2002). Sosiologi Skematika, Teori, dan Terapan. Jakarta: Bumi Aksara.

Chaer, A. (2007). Leksikologi dan Leksikografi Indonesia. Jakarta: Rineka Cipta.

Dahliani. (2014). Eksistensi Rumah Tradisional Banjar sebagai Identitas Kawasan Bersejarah di Kelurahan Kuin Utara, Banjarmasin. Jurnal Modul, 14 (1), 1--10.

Ibnu, S., \& Dkk. (2003). Dasar-dasar Metodologi Penelitian. Malang: Lembaga Penelitian Universitas Negeri Malang.

Kridalaksana, H. (2011). Kamus Linguistik. Jakarta: Gramedia Pustaka Utama.

Mahsun. (2017). Metode Penelitian Bahasa Tahapan, Strategi, Metode, dan Tekniknya. Jakarta: Rajagrafindo Persada.

Moleong, L. J. (2015). Metodologi Penelitian Kualitatif. Bandung: Remaja Rosdakarya.

Mulyana, R. (2004). Mengartikulasikan
Pendidikan Nilai. Bandung: Alfabeta.

Nuralang, A. (2006). "Pelabuhan sebagai Penghubung Jalan Laut dan Darat". Naditira Widya, 16, 48--54.

Nurhafni. (2017). Eksistensi Rumah Tradisional Uma Lengge sebagai Destinasi Wisata Budaya di Nusa Tenggara Barat (pp. 575--525).

Priambada, A. F. (2011). Bentuk dan Makna Leksikon Pembentuk Rumah Adat Kudus. Universitas Negeri Semarang.

Redaksi, T. (2009). Tesaurus Alfabetis Bahasa Indonesia. Jakarta: Pusat Bahasa.

Santosa, R. (2014). Metode Penelitian Kualitatif Kebahasaan. Surakarta: Universitas Sebelas Maret.

Saodih, S. N. (2010). Metode Penelitian Pendidikan. Jakarta: Remaja Rosdakarya.

Setiadi, E. dkk. (2017). Ilmu Sosial dan Budaya Dasar. Jakarta: Kencana.

Silalahi, U. (2012). Metode Penelitian Sosial. Bandung: Refika Aditama.

Sudaryanto. (2015). Metode dan Aneka Teknik Analisis Bahasa Pengantar Penelitian Wahana Kebudayaan secara Linguistis. Yogyakarta: Sanata Dharma University Press.

Sudikan, S. Y. (2017). "Ragam Metode Pengumpulan Data Mengulas Kembali: Pengamatan, Wawancara, Analisis Life History, Analisis Folklore". Dalam Bungin (ed.), Metodologi Penelitian 
Klasifikasi Leksikon dan Fungsi...

Kualitatif Aktualisasi Metodologis ke Arah Ragam Varian Kontemporer. Jakarta: Rajagrafindo Persada.

Sumantri \& Sauri. (2006). Konsep Dasar Pendidikan Nilai. Bandung: Pribumi.

Verhaar, J. W. M. (2006). Asas-Asas Linguistik Umum. Yogyakarta: Gadjah Mada University Press. 